\title{
Hyponatremia in spinal cord injury patients: new insight into differentiating between the dilution and depletion forms
}

\author{
J Kriz ${ }^{1}$, O Schuck ${ }^{2}$ and M Horackova ${ }^{2}$
}

Study design: This is a retrospective study.

Objectives: The objectives of this study were to present a new model for differentiating between the dilution and depletion forms of hyponatremia in patients in the postacute phase after spinal cord injury (SCI), and to identify possible etiological factors contributing to hyponatremia in these patients.

Setting: University Hospital Motol, Prague, Czech Republic.

Methods: Eighty-seven of 352 patients hospitalized in 2008-2012 in the Spinal Cord Unit were hyponatremic. Seventy-four patients had $\mathrm{S}_{\mathrm{Na}+}=130-135 \mathrm{mmol}^{-1}$ and 13 patients had $\mathrm{S}_{\mathrm{Na}+}$ below $130 \mathrm{mmol}^{-1}$. We propose a simple model of an electrolyte solution in which the $\mathrm{Na}^{+}$concentration is higher than the $\mathrm{Cl}^{-}$concentration, making it possible to compare the effects of dilution and depletion of $\mathrm{Na}^{+}$and $\mathrm{Cl}^{-}$on the $\mathrm{Na}^{+}$concentration. The depletion of $\mathrm{Na}^{+}$and $\mathrm{Cl}^{-}$leads to a significant increase in the $\mathrm{Na}^{+} / \mathrm{Cl}^{-}$ratio, with the $\mathrm{Na}^{+}-\mathrm{Cl}^{-}$value remaining unchanged. Dilution with water results in a decrease of $\mathrm{Na}^{+}-\mathrm{Cl}^{-}$with the $\mathrm{Na}^{+} / \mathrm{Cl}^{-}$ratio remaining unchanged. Results: In patients with $\mathrm{S}_{\mathrm{Na}}$ below $130 \mathrm{mmol} \mathrm{I}^{-1}$, hyponatremia was consistent with the depletion model in $46 \%$ and with the dilution model in $32 \%$. In patients with $\mathrm{S}_{\mathrm{Na}+}$ ranging between 130 and $135 \mathrm{mmol}^{-1}$, the respective rates were 34 and $12 \%$.

Conclusion: Examination of $\mathrm{S}_{\mathrm{Na}+}-\mathrm{S}_{\mathrm{Cl}-}$ and $\mathrm{S}_{\mathrm{Na}+} / \mathrm{S}_{\mathrm{Cl}}$ in patients with $\mathrm{SCl}$ could be helpful in considering whether hyponatremia is consistent either with the $\mathrm{NaCl}$ dilution model or with the $\mathrm{NaCl}$ depletion model. Further studies are needed for more accurate interpretation of the results, particularly with respect to volume and acid-base disorders.

Spinal Cord (2015) 53, 291-296; doi:10.1038/sc.2014.240; published online 13 January 2015

\section{INTRODUCTION}

Spinal cord injury (SCI) results in impaired function of the somatic and autonomic nervous systems below the level of injury. One of the consequences of SCI is the presence of metabolic abnormalities. The prevalence of hyponatremia is significantly higher in SCI patients compared with other diseases or postsurgical conditions. ${ }^{1}$ Hyponatremia is most often reported within the first 2 weeks after $\mathrm{SCI},{ }^{2}$ but it can be observed even later. ${ }^{3}$ The cause is multifactorial; however, etiological factors involved in the development of hyponatremia in SCI patients differ, in part, from those in the general population. ${ }^{3,4}$

When considering hyponatremia, it is necessary to differentiate whether the cause is water retention (dilution hyponatremia) or loss of $\mathrm{Na}^{+}$and $\mathrm{Cl}^{-}$(depletion hyponatremia). Dilution hyponatremia is mainly caused by inappropriate secretion of antidiuretic hormone (SIADH), whereas depletion hyponatremia results from an increase of renal or extrarenal natrium wasting. If the renal wasting is related to brain injury, it is called cerebral salt wasting syndrome. Differentiation between these two forms is difficult, and primarily it is diagnosed on the basis of volume change observation. ${ }^{5,6}$

Differential diagnosis between dilution and depletion hyponatremia is essential for appropriate therapy. Patients with sodium loss would benefit only from sodium provision, whereas those with fluid overload would benefit from fluid restriction or water diuresis. Decrease in the serum sodium concentration $\left(\mathrm{S}_{\mathrm{Na}+}\right)$ needs to go along with a reduced anion concentration. From the quantitative perspective, changes in the concentrations of chlorides $\left(\mathrm{S}_{\mathrm{Cl}-}\right)$ and bicarbonates $\left(\mathrm{S}_{\mathrm{HCO} 3-}\right)$ are likely to occur. The changes to the $\mathrm{S}_{\mathrm{Cl}}$ - to $\mathrm{S}_{\mathrm{HCO} 3}$ - concentration ratio in the presence of hyponatremia may vary widely, and therefore the development of hyponatremia can be associated with changes to the acid-base balance. The $\mathrm{S}_{\mathrm{Na}+} / \mathrm{S}_{\mathrm{Cl}}$ - ratio and $\mathrm{S}_{\mathrm{Na}+}-\mathrm{S}_{\mathrm{Cl}}$ - difference have been used successfully in the differential diagnosis of acid-base balance disorders. ${ }^{7-11}$ These findings challenged us to investigate whether the above-mentioned values vary concordantly or independently in dilution and depletion hyponatremia and whether their calculation could be helpful in the differential diagnosis between dilution and depletion hyponatremia. We designed a simple model of an electrolyte solution in which the $\mathrm{Na}^{+}$concentration was higher than the $\mathrm{Cl}^{-}$ concentration, similarly as is the case in the extracellular fluid, to see how dilution with water and depletion of $\mathrm{NaCl}$ influence the $\mathrm{Na}^{+}-\mathrm{Cl}^{-}$ and $\mathrm{Na}^{+} / \mathrm{Cl}^{-}$values. On the basis of these findings, we want to specify whether the diagnosis of hyponatremia in SCI patients is consistent either with the dilution model or the $\mathrm{NaCl}$ depletion model.

\section{PATIENTS AND METHODS}

Laboratory data of patients hospitalized in the Spinal Cord Unit (SCU) were analyzed retrospectively for the 5-year period 2008-2012. The hospitalized cohort included 352 patients with acute SCI. Eighty-seven patients had, at least once, the serum $\mathrm{Na}^{+}$level below the limit of $135 \mathrm{mmoll}^{-1}$. The mean age of these 87 patients at the time of SCI was $51.1 \pm 17.5$ years. They were admitted to the SCU with an average interval of 44.3 days after SCI. The patients were 
grouped according to the severity of hyponatremia. ${ }^{12}$ Seventy-four patients were assigned to class I $\left(\mathrm{S}_{\mathrm{Na}+}=130-135 \mathrm{mmoll}^{-1}\right)$, six patients to class II $\left(\mathrm{S}_{\mathrm{Na}+}=125-129 \mathrm{mmoll}^{-1}\right)$ and seven patients to class III ( $\mathrm{S}_{\mathrm{Na}+} 115-124$ mmol $1^{-1}$ ) (Table 1). None of the patients in the study met the class IV criteria $\left(\mathrm{S}_{\mathrm{Na}+}<115 \mathrm{mmoll}^{-1}\right)$. All study patients were also checked for levels of other ions, creatinine, plasma osmolality and CRP and most patients assigned to classes II and III also checked for urine $\mathrm{Na}^{+}$and $\mathrm{Cl}^{-}$and urine osmolality.

The main goal of the differential diagnosis is to determine whether hyponatremia is due to dilution or depletion of $\mathrm{Na}^{+}$and $\mathrm{Cl}^{-}$. Differentiating between these two forms is of high importance, as it influences the choice of therapeutic regimen. The potential of the $\mathrm{S}_{\mathrm{Na}+}-\mathrm{S}_{\mathrm{Cl}}$ - and $\mathrm{S}_{\mathrm{Na}+} / \mathrm{S}_{\mathrm{Cl}}$ - for use in the differential diagnosis between the two types of hyponatremia was supported by the following generally accepted hypotheses. When considering changes in the $\mathrm{Na}^{+}$concentration, it is assumed that the distribution volume of $\mathrm{Na}^{+}$ correlates with total body water. ${ }^{13}$ The simple mathematical model proposed by us is a single-compartment system, as the body maintains isotonicity of the extracellular fluid with the intracellular fluid and the shifts of water between these two compartments influence accordingly the $\mathrm{Na}^{+}$and $\mathrm{Cl}^{-}$concentrations. Figure 1 shows a compartment with 201 of electrolyte solution containing $\mathrm{Na}^{+}$ $\left(140 \mathrm{mmoll}^{-1}\right), \mathrm{Cl}^{-}\left(100 \mathrm{mmoll}^{-1}\right)$ and $\mathrm{HCO}_{3}{ }^{-}\left(40 \mathrm{mmoll}^{-1}\right)$. On the upper panel of the figure, two liters of water are added to model the dilution. Consequently, the $\mathrm{Na}^{+}-\mathrm{Cl}^{-}$decreases from 40 to $36 \mathrm{mmoll}^{-1}$. On the other hand, the $\mathrm{Na}^{+} / \mathrm{Cl}^{-}$remains unchanged (1.40). The lower panel of the figure

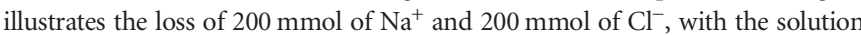
volume remaining unchanged. Under such conditions, the $\mathrm{Na}^{+}-\mathrm{Cl}^{-}$remains unchanged, but the $\mathrm{Na}^{+} / \mathrm{Cl}^{-}$increases to 1.44 . This serves as a model of the $\mathrm{Na}^{+}$ depletion. If the solution volume decreased, for example, by 11 , the $\mathrm{Na}^{+} / \mathrm{Cl}^{-}$ would remain unchanged, but the $\mathrm{Na}^{+}-\mathrm{Cl}^{-}$would increase. Renal sodium wasting is associated with the loss of both ions. If more $\mathrm{Cl}^{-}$than $\mathrm{Na}^{+}$were lost, both the $\mathrm{Na}^{+} / \mathrm{Cl}^{-}$and $\mathrm{Na}^{+}-\mathrm{Cl}^{-}$would increase.

To enable the use of the above-mentioned simple model in clinical practice, the normal ranges of the $\mathrm{S}_{\mathrm{Na}+}-\mathrm{S}_{\mathrm{Cl}}$ and $\mathrm{S}_{\mathrm{Na}+} / \mathrm{S}_{\mathrm{Cl}}$ - need to be established in healthy individuals. For these reasons, 33 healthy adults, health-care professionals, with average eating habits were investigated. The following means and s.d. were obtained for the parameters under study: $\mathrm{S}_{\mathrm{Na}+}-\mathrm{S}_{\mathrm{Cl}-}=35.0 \pm 1.6 \mathrm{mmoll}^{-1}$ and $\mathrm{S}_{\mathrm{Na}+} / \mathrm{S}_{\mathrm{Cl}-}=1.33 \pm 0.02$. The normal ranges calculated as mean \pm 2 s.d. were $31.8-38.3 \mathrm{mmoll}^{-1}$ and $1.29-1.37 \mathrm{mmoll}^{-1}$, respectively.

Table 1 Characteristics of the study population

\begin{tabular}{|c|c|c|c|c|c|c|}
\hline \multirow[t]{2}{*}{ Class (mmoll-1) } & \multicolumn{2}{|c|}{ I. $(130-135)$} & \multicolumn{2}{|c|}{ II. (125-129) } & \multicolumn{2}{|c|}{ III. (115-124) } \\
\hline & $\mathrm{N}$ & $\%$ & $\mathrm{~N}$ & $\%$ & $\mathrm{~N}$ & $\%$ \\
\hline \multicolumn{7}{|l|}{ Sex } \\
\hline Male & 56 & 75.7 & 3 & 50.0 & 6 & 85.7 \\
\hline Female & 18 & 24.3 & 3 & 50.0 & 1 & 14.3 \\
\hline \multicolumn{7}{|l|}{$N L I$} \\
\hline C & 31 & 41.9 & 5 & 83.3 & 5 & 71.4 \\
\hline $\mathrm{T}$ & 27 & 36.5 & 1 & 16.7 & 2 & 28.6 \\
\hline L & 16 & 21.6 & 0 & 0.0 & 0 & 0.0 \\
\hline \multicolumn{7}{|l|}{$A / S$} \\
\hline A & 32 & 43.2 & 3 & 50.0 & 2 & 28.6 \\
\hline$B-D$ & 42 & 56.8 & 3 & 50.0 & 5 & 71.4 \\
\hline \multicolumn{7}{|l|}{ Cause } \\
\hline Traumatic & 55 & 74.3 & 3 & 50.0 & 5 & 71.4 \\
\hline Nontraumatic & 19 & 25.7 & 3 & 50.0 & 2 & 28.6 \\
\hline Total & 74 & 100.0 & 6 & 100.0 & 7 & 100.0 \\
\hline
\end{tabular}

To what extent the above-mentioned model is consistent with the known clinical findings of changes in $\mathrm{S}_{\mathrm{Na}+}-\mathrm{S}_{\mathrm{Cl}-}$ and $\mathrm{S}_{\mathrm{Na}+} / \mathrm{S}_{\mathrm{Cl}}$ - in altered acid-base balance associated with volume changes is commented on in the Discussion section.

The following step was the identification of all factors possibly involved in the development of hyponatremia in each individual patient. We considered factors responsible for water retention and those responsible for increased loss of $\mathrm{Na}^{+}$and $\mathrm{Cl}^{-}$.

\section{RESULTS}

\section{Classes II and III $\left(\mathrm{S}_{\mathrm{Na}+}=115-129 \mathrm{mmoll}^{-1}\right)$}

Hyponatremia in the range shown above was found in 13 SCI patients. Their basic laboratory test results are summarized in Table 2 . The level of hyponatremia below $135 \mathrm{mmoll}^{-1}$ was detected with a mean of 13.6 times in this group. From the table, it is evident that in all these patients hyponatremia was associated with a decrease in $\mathrm{S}_{\mathrm{Cl}-}\left(<97 \mathrm{mmoll}^{-1}\right)$ and $\mathrm{S}_{\mathrm{osm}}\left(<295 \mathrm{mmol} \mathrm{kg}^{-1}\right)$. The $\mathrm{S}_{\mathrm{Na}+}-\mathrm{S}_{\mathrm{Cl}-}$ was below the lower limit of the normal range $\left(<32 \mathrm{mmoll}^{-1}\right)$ in four patients, and in one patient it was close to the limit value. The upper limit of the normal range $(>37 \mathrm{mmol} /)$ was exceeded in four patients, whereas in the other patients under study the values were in the normal range. In five patients, the $\mathrm{S}_{\mathrm{Na}+} / \mathrm{S}_{\mathrm{Cl}}$ - was above the upper limit of the normal range $(>1.37)$, in two patients this ratio was close to the limit and in the remaining patients this ratio was in the normal range.

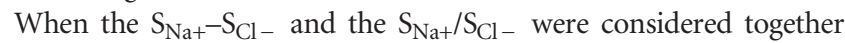
(Table 3), the dilution model was applicable to four patients (decreased $\mathrm{S}_{\mathrm{Na}+}-\mathrm{S}_{\mathrm{Cl}-}$ and the $\mathrm{S}_{\mathrm{Na}+} / \mathrm{S}_{\mathrm{Cl}-}$ in the normal range). The depletion model was applicable to seven patients (increased $\mathrm{S}_{\mathrm{Na}+} / \mathrm{S}_{\mathrm{Cl}}$ and the $\mathrm{S}_{\mathrm{Na}+}-\mathrm{S}_{\mathrm{Cl}}$ in the normal range or increased).

The $\mathrm{U}_{\mathrm{osm}}$ value was above $100 \mathrm{mmol} \mathrm{kg}^{-1}$ in all patients, being higher than $\mathrm{S}_{\mathrm{osm}}$ in six of them. The urinary concentration of $\mathrm{Na}^{+}$was above $30 \mathrm{mmoll}^{-1}$ in all but one patients. The urinary $\mathrm{Na}^{+} / \mathrm{Cl}^{-}$ $\left(\mathrm{U}_{\mathrm{Na}+} / \mathrm{U}_{\mathrm{Cl}-}\right)$ was close to 1.0 (with a mean of 0.994 ). From Table 2, it is evident that the serum creatinine concentrations were very low (29-99 $\left.\mu \mathrm{moll}^{-1}\right), 50 \mu \mathrm{moll}{ }^{-1}$ on average.

Of four patients assigned to the dilution hyponatremia group, two had acute urinary infection, and in the three patients the cause of hyponatremia may have been the synthetic antidiuretic hormone $(\mathrm{ADH})$ given to treat polyuria. Moreover, all these patients took antidepressants, one of them in combination with antiepileptics, and two patients had pronounced arterial hypotension. In six patients with depletion hyponatremia, the cause may have been impaired autonomic regulation of kidney function.

\section{Class I $\left(\mathrm{S}_{\mathrm{Na}+}=130-135 \mathrm{mmol}^{-1}\right)$}

Seventy-four $(85.1 \%)$ patients had hyponatremia, with the $\mathrm{S}_{\mathrm{Na}}$ serum levels between 130 and $135 \mathrm{mmol}^{-1}$ and $\mathrm{S}_{\mathrm{Cl}}$ - serum levels between 89 and $106 \mathrm{mmoll}^{-1}$. Hyponatremia was detected most often only once, with a mean of 3.2 times. In these mildly hyponatremic patients, serum electrolytes were only checked and the $\mathrm{S}_{\mathrm{Na}+}-\mathrm{S}_{\mathrm{Cl}-}$ and $\mathrm{S}_{\mathrm{Na}+} / \mathrm{S}_{\mathrm{Cl}}$ - were calculated. The values of the $\mathrm{S}_{\mathrm{Na}+}-\mathrm{S}_{\mathrm{Cl}-}$ and $\mathrm{S}_{\mathrm{Na}+} / \mathrm{S}_{\mathrm{Cl}-}$ established for individual patients are shown in Figure 2. The results are summarized in Table 3, from which it is evident that the dilution model was applicable to four patients (decrease in the $\mathrm{S}_{\mathrm{Na}+}-\mathrm{S}_{\mathrm{Cl}-}$ and the $\mathrm{S}_{\mathrm{Na}+} / \mathrm{S}_{\mathrm{Cl}}$ in the normal range), and five patients had lower values of $\mathrm{S}_{\mathrm{Na}+}-\mathrm{S}_{\mathrm{Cl}-}$ and at the same time lower $\mathrm{S}_{\mathrm{Na}+} / \mathrm{S}_{\mathrm{Cl}-}$. The depletion model was applicable to 29 patients (increase in the $\mathrm{S}_{\mathrm{Na}+} / \mathrm{S}_{\mathrm{Cl}-}$ and the $\mathrm{S}_{\mathrm{Na}+}-\mathrm{S}_{\mathrm{Cl}-}$ in the normal range or elevated).

Of nine patients with dilution hyponatremia, six had acute infection and five of these had urinary infection at presentation. The others had 


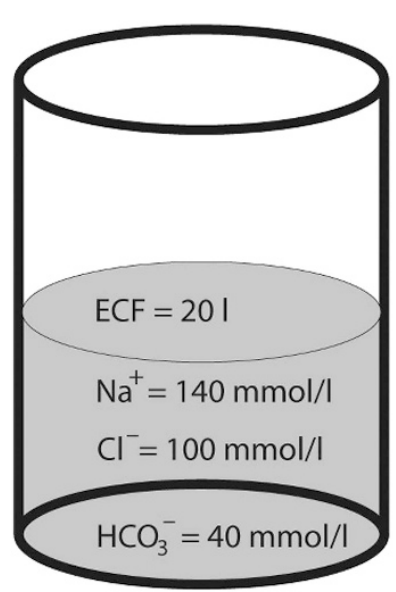

$\mathrm{Na}^{+}-\mathrm{Cl}^{-}=\mathbf{4 0} \quad \mathrm{Na}^{+} / \mathrm{Cl}^{-}=\mathbf{1 . 4 0}$

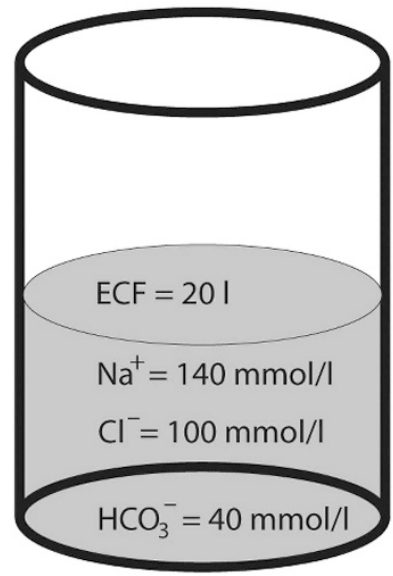

$\mathrm{Na}^{+}-\mathrm{Cl}^{-}=\mathbf{4 0} \quad \mathrm{Na}^{+} / \mathrm{Cl}^{-}=\mathbf{1 . 4 0}$

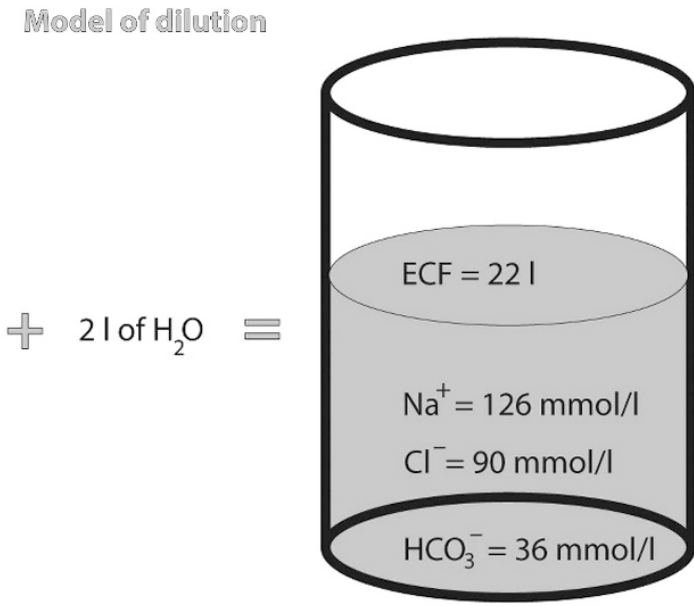

$\mathrm{Na}^{+}-\mathrm{Cl}^{-}=\mathbf{3 6} \quad \mathrm{Na}^{+} / \mathrm{Cl}^{-}=\mathbf{1 . 4 0}$

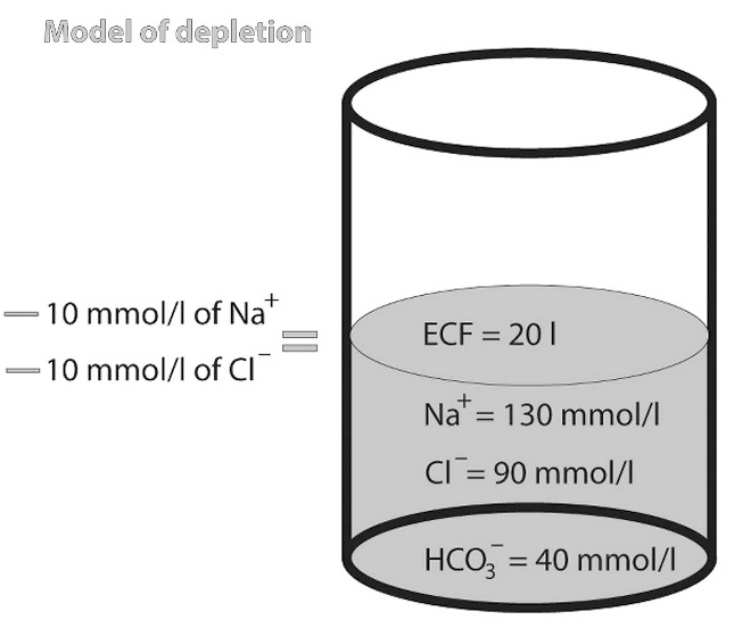

$\mathrm{Na}^{+}-\mathrm{Cl}^{-}=\mathbf{4 0} \quad \mathrm{Na}^{+} / \mathrm{Cl}^{-}=\mathbf{1 . 4 4}$

Figure 1 Mathematical model to illustrate the $\mathrm{Na}^{+}-\mathrm{Cl}^{-}$and $\mathrm{Na}^{+} / \mathrm{Cl}^{-}$changes after water retention or $\mathrm{Na}^{+}$and $\mathrm{Cl}^{-}$depletion. Abbreviations: ECF, extracellular fluid; $\mathrm{Na}^{+}$, sodium; $\mathrm{Cl}^{-}$, chloride; $\mathrm{HCO}_{3}{ }^{-}$bicarbonate; $\mathrm{H}_{2} \mathrm{O}$, water; $\mathrm{Na}^{+}-\mathrm{Cl}^{-}$, sodium-chloride difference; $\mathrm{Na}^{+} / \mathrm{Cl}^{-}$, sodium-chloride ratio.

pronounced arterial hypotension. All patients were treated by antidepressants and two of them in combination with antiepileptics. In 29 patients, depletion hyponatremia might be caused by impaired autonomic regulation of kidney function. Other factors that may have had a role in hyponatremia were significantly low blood pressure (systolic blood pressure below 100) in 14 patients, diuretics given to control chronic arterial hypertension in four patients, diarrhea in one patient and vomiting in one patient.

Practically in all study patients, multiple factors possibly involved in the development of hyponatremia were identified. These factors are listed and their distribution is presented in Table 4.

\section{DISCUSSION}

In the literature, higher prevalence of hyponatremia has been generally reported in SCI or surgery patients. The rates of hyponatremia reported in SCI patients range from 25 to $80 \% .^{1,2,4}$ Nevertheless, these rates relate to the patients in the acute phase or in the first month after SCI. In our cohort of 352 patients admitted to the SCU on day 44 following SCI on average, $24.7 \%$ had hyponatremia.
In general, it is difficult to differentiate between the two types of hyponatremia and thereby select the appropriate treatment. After establishing $\mathrm{S}_{\mathrm{Na}+}-\mathrm{S}_{\mathrm{Cl}-}$ and $\mathrm{S}_{\mathrm{Na}+} / \mathrm{S}_{\mathrm{Cl}-}$, it is possible to consider which of the models is applicable to hyponatremia diagnosed in a particular patient. Verifying whether the conclusion is correct would require simultaneous measurement of volume changes. These data are not available to our study cohort, but there is indirect evidence for differentiating between dilution and depletion hyponatremia on the basis of clinical findings in altered acid-base balance associated with volume changes. Dilution owing to water retention results in dilutional acidosis, characterized by a decrease in strong ion difference (SID). ${ }^{14}$ Reduced SID correlates significantly with a decrease in $\mathrm{S}_{\mathrm{Na}+}-\mathrm{S}_{\mathrm{Cl}-}$ (i.e., with the same changes as seen in the dilution model). ${ }^{7}$ Large renal losses of $\mathrm{Na}^{+}, \mathrm{Cl}^{-}$and water resulting from intensive therapy with diuretics can lead to hypovolemia and hypochloremic metabolic alkalosis. ${ }^{15,16}$ Such an alteration of electrolyte and volume homeostasis is associated with increased $\mathrm{S}_{\mathrm{Na}+}-\mathrm{S}_{\mathrm{Cl}}$ and $\mathrm{S}_{\mathrm{Na}+} / \mathrm{S}_{\mathrm{Cl}-}$ (or decreased $\left.\mathrm{S}_{\mathrm{Cl}-} / \mathrm{S}_{\mathrm{Na}+}\right)^{7}$ (with the same changes as observed in the depletion model). 
All patients whose urine $\mathrm{Na}^{+}$and $\mathrm{Cl}^{-}$concentrations and osmolality were also analyzed had $\mathrm{U}_{\mathrm{OSM}}$ levels above $100 \mathrm{mmol} \mathrm{kg}^{-1}$, and all but one had $\mathrm{U}_{\mathrm{Na}+}$ levels above $30 \mathrm{mmol}^{-1}$. These results, in the presence of hyponatremia, are in accordance with the most used laboratory criteria, of SIADH and, consequently, of dilution hyponatremia. ${ }^{6} \mathrm{We}$ assume that the discrepancy between the commonly used approaches in the assessment of laboratory data indicative of SIADH and differentiation between the two types of hyponatremia based on

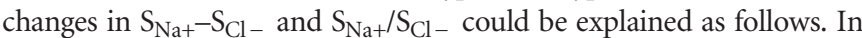
hyponatremia due to renal depletion of $\mathrm{Na}^{+}$and $\mathrm{Cl}^{-}$(renal salt wasting syndrome), it is understandable that the urine $\mathrm{Na}$ concentrations exceed the criterion of $20 \mathrm{mmoll}^{-1}$ and are often even higher than $30 \mathrm{mmoll}^{-1}$. Depletion of $\mathrm{Na}^{+}$and $\mathrm{Cl}^{-}$is associated with hypovolemia, which induces nonosmotic activation of $\mathrm{ADH}$ secretion. An increased $\mathrm{ADH}$ level enhances tubular reabsorption of water, and thus the $\mathrm{U}_{\mathrm{OSM}}$ level tends toward an increase and can exceed not only $100 \mathrm{mmol} \mathrm{kg}^{-1}$ but also the $\mathrm{S}_{\mathrm{OSM}}$ level. It means that in depletion hyponatremia laboratory symptoms considered typical of SIADH may develop. Under such conditions, $\mathrm{ADH}$ secretion is stimulated. It is not inappropriate as is the case in SIADH, but it occurs as a physiological response to hyponatremia owing to extracellular fluid volume reduction, resulting mainly from the decrease in effective intravascular volume. Nevertheless, in patients with SIADH, $\mathrm{ADH}$ secretion is not stimulated as a result of regulation of volume homeostasis of the internal environment, but it is triggered by various pathogenetic or pharmacological stimuli.

In the light of the above-mentioned pathophysiological phenomena, it is evident that the laboratory criteria used for the urinary $\mathrm{Na}^{+}$ concentrations and osmolality may not differentiate between SIADH and renal salt wasting in the presence of hyponatremia. In our opinion, apart from the criteria used, it would be helpful, for example, to differentiate between increased $\mathrm{ADH}$ production as a physiological response to hypovolemia (even in the presence of hyponatremia and reduction of extracellular fluid osmolality) and a pathological response resulting in inappropriate $\mathrm{ADH}$ secretion. The results of the present study and the presented differential diagnostic hypothesis for dilution and depletion hyponatremia suggest that in addition to the criteria

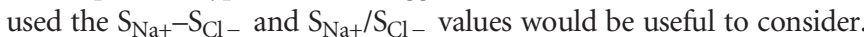
However, further study of the relationship between the abovementioned values and volume changes will be needed to test this assumption.

Differentiating between dilution and depletion hyponatremia also provides a crucial sign as to the use of vaptans (drugs that increase solute-free water excretion). In accordance with the current pathophysiological knowledge, vaptans are expected to be effective in dilution hyponatremia where water excretion needs to be enhanced (without influencing $\mathrm{Na}^{+}$excretion). In patients with depletion hyponatremia showing signs of hypovolemia, pharmacological reduction of tubular water resorption could deepen the water deficit in the body and aggravate the hemodynamic manifestations of hypovolemia. Current practice has been considered in the US evidence based and expert panel reviewed guidelines ${ }^{17}$ and in European practice guideline on diagnosis and treatment of hyponatremia. ${ }^{18}$

Future research will also require a thorough clinical evaluation of the potential therapeutic benefit of the proposed approach for the treatment of hyponatremia in SCI patients.

The reason behind the higher incidence of hyponatremia in SCI patients is most likely because of the impairment of the autonomic nervous system. The loss of peripheral vascular resistance in patients with impairment of sympathetic vascular innervation after cervical and upper thoracic cord injuries results in chronic arterial hypotension and 
Table 3 Various combinations of changes in serum sodium-serum chloride difference and serum sodium-serum chloride ratio

\begin{tabular}{|c|c|c|c|c|c|c|c|}
\hline$N$ & $\begin{array}{c}\mathrm{S}_{\mathrm{Na}+} \\
m m o l 1^{-1}\end{array}$ & $\begin{array}{c}S_{C l-} \\
m m o l I^{-1}\end{array}$ & $\begin{array}{l}S_{\mathrm{Na}+}-S_{\mathrm{Cl}-} \\
S_{\mathrm{Na}+} / S_{\mathrm{Cl}-} \rightarrow\end{array}$ & $\begin{array}{l}S_{\mathrm{Na}+}-S_{C l-} \mathbf{y} \\
S_{\mathrm{Na}+} / S_{\mathrm{Cl}-} \mathbf{y}\end{array}$ & $\begin{array}{l}S_{\mathrm{Na}+}-S_{C l-} \rightarrow \\
S_{\mathrm{Na}+} / S_{C l-} \rightarrow\end{array}$ & $\begin{array}{l}S_{\mathrm{Na}+}-S_{C l-} \boldsymbol{\eta} \\
S_{\mathrm{Na}+} / S_{C l-} \boldsymbol{\eta}\end{array}$ & $\begin{array}{l}S_{\mathrm{Na}+}-S_{C l-} \rightarrow \\
S_{\mathrm{Na}+} / S_{C l-} \rightarrow\end{array}$ \\
\hline 13 & 115-129 & $80-94$ & $4(30.8 \%)$ & $0(0 \%)$ & $3(23.1 \%)$ & $3(23.1 \%)$ & $3(23.1 \%)$ \\
\hline
\end{tabular}

Abbreviations: $\mathrm{S}_{\mathrm{Na}+}-\mathrm{S}_{\mathrm{Cl}-}$, serum sodium-serum chloride difference; $\mathrm{S}_{\mathrm{Na}+} / \mathrm{S}_{\mathrm{Cl}-}$, serum sodium-serum chloride ratio; $\boldsymbol{y}$, decreased; $\boldsymbol{\eta}$, in range; $\boldsymbol{\eta}$, increased.
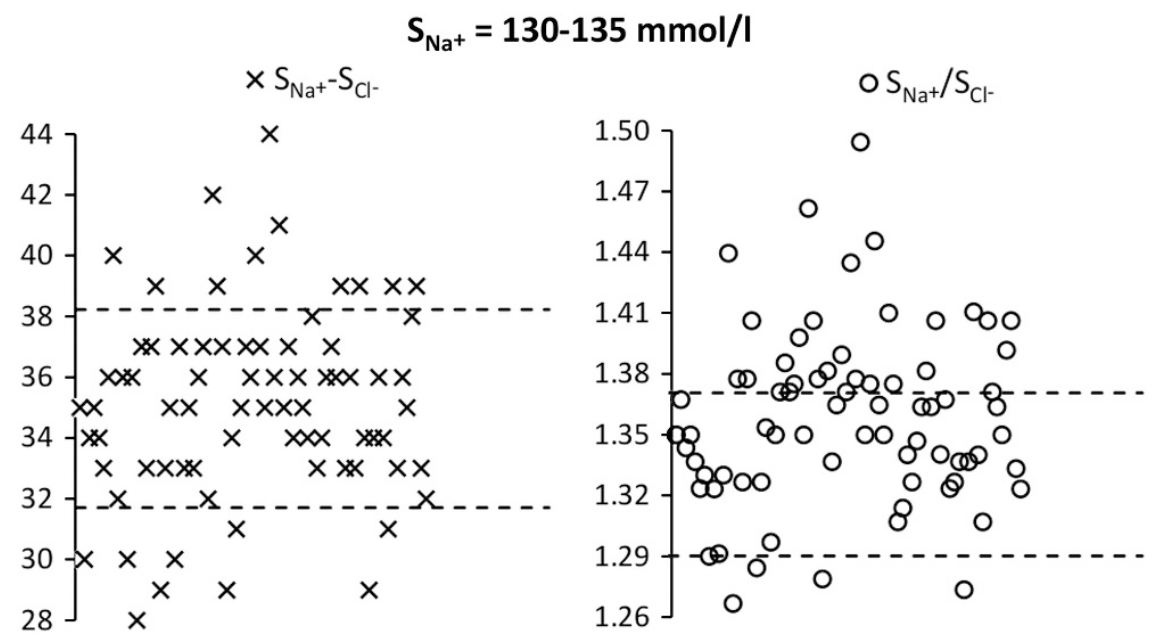

Figure 2 The values of $\mathrm{S}_{\mathrm{Na}+}-\mathrm{S}_{\mathrm{Cl}-}$ and $\mathrm{S}_{\mathrm{Na}+} / \mathrm{S}_{\mathrm{Cl}-}$ in class I $\left(\mathrm{S}_{\mathrm{Na}+}=130-135 \mathrm{mmol}{ }^{-1}\right)$. Borderlines denote the normal range of $\mathrm{S}_{\mathrm{Na}+}-\mathrm{S}_{\mathrm{Cl}-}$ and $\mathrm{S}_{\mathrm{Na}+} / \mathrm{S}_{\mathrm{Cl}-}$.

Table 4 Etiological factors considering to cause hyponatremia in $\mathrm{SCl}$ patients

\begin{tabular}{lrr}
\hline & $\mathrm{N}$ & $\%$ \\
\hline Total no. of hyponatremic patients & 87 & 100.0 \\
Renal sympathetic disruption & 87 & 100.0 \\
Diarrhea & 4 & 4.6 \\
Vomiting & 2 & 2.3 \\
Tumor & 3 & 3.4 \\
Diuretics & 7 & 8.0 \\
Significant hypotension & 33 & 37.9 \\
Urinary tract infection & 30 & 34.5 \\
Other infection or sepsis & 10 & 11.5 \\
& & \\
Antidepressant & & 77.0 \\
$\quad$ SSRIs & 67 & 2.3 \\
SNRIs & 2 & 11.5 \\
Others & 10 & \\
Antiepileptics & & 5.7 \\
Desmopressin & 17 & \\
\hline
\end{tabular}

Abbreviations: SSRIs, selective serotonin reuptake inhibitors; SNRIs, serotonin-norepinephrine reuptake inhibitors.

orthostatic hypotension. As a nonosmotic stimulus, hypotension exerts an effect on the secretion of $\mathrm{ADH}$. The stimulating effect of hypotension overcomes the inhibitory effect of hypotonicity. Thus, water is retained in the body despite serum hyponatremia. ${ }^{2,19,20}$ Damage to the autonomic conduction paths also alters kidney function. The impairment of the renal sympathetic innervation manifests itself in reduced renal blood flow, lower tubular secretion of angiotensin II and renin production by the juxtaglomerular granular cells and decreased tubular reabsorption of $\mathrm{Na}^{+}$and water. ${ }^{4}$ As the renal sympathetic innervation arises from spinal cord levels T11-L3, ${ }^{21}$ changes in renal function occur in patients with SCI at any level. Therefore, damage to the autonomic nervous system may enhance both water retention and $\mathrm{Na}^{+}$excretion. Consequently, a combination of dilution and depletion hyponatremia develops. Apart from small changes in the $\mathrm{S}_{\mathrm{Na}+}-\mathrm{S}_{\mathrm{Cl}-}$ and $\mathrm{S}_{\mathrm{Na}+} / \mathrm{S}_{\mathrm{Cl}-}$, this may be another reason for failure to classify the condition in nearly half of the study patients.

Another often reported cause of nonosmotic stimulation of inappropriate secretion of $\mathrm{ADH}$ is stress associated with a severe infectious insult. This may be an acute chest infection, urinary infection or some other septic condition. ${ }^{3,22}$ Nonosmotic stimulation of $\mathrm{ADH}$ secretion may also be caused by various types of drugs such as antidepressants, specifically selective serotonin reuptake inhibitors, antipsychotics or antiepileptics, which are being reported most often in this context. ${ }^{23}$ Atsariyasing and Goldman also recorded antipsychotics-induced hyponatremia. They used the urine osmolality to distinguish it from psychosis-induced hyponatremia. ${ }^{24}$ In both cases, the dilution form was presented. In our study, the evaluation of urine osmolality was not sufficient to distinguish between the dilution and depletion forms.

Altered osmotic regulation of $\mathrm{ADH}$ secretion, a reset osmostat, resulting in $\mathrm{ADH}$ release at a lower osmotic threshold has been discussed as a possible cause of hyponatremia in SCI patients. ${ }^{2}$ The osmostat set point can also be shifted iatrogenically owing to excessive volume therapy, possibly inappropriately indicated to control the hemodynamic response to neurogenic shock following SCI. However, neurogenic shock develops as a result of the loss of autonomic nervous system function below the level of the lesion and needs to be treated differently from hypovolemic shock. ${ }^{25}$ 


\section{CONCLUSION}

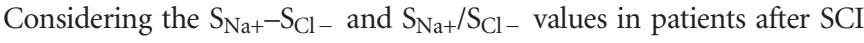
associated with hyponatremia may be helpful in differentiating whether the decreased $\mathrm{S}_{\mathrm{Na}+}$ is consistent with the proposed dilution model (SIADH) or the $\mathrm{NaCl}$ depletion model (renal salt wasting). Further research is needed to evaluate the relationship between the above-mentioned values and volume changes.

\section{Limits of the study}

In this retrospective study, acid-base balance was not systematically analyzed. An assessment of the clinical outcome of therapeutic approach used could not be made and related to the assumed type of hyponatremia.

\section{DATA ARCHIVING}

There were no data to deposit.

\section{CONFLICT OF INTEREST}

The authors declare no conflict of interest.

1 Peruzzi WT, Shapiro BA, Meyer PR Jr, Krumlovsky F, Seo BW. Hyponatremia in acute spinal cord injury. Crit Care Med 1994; 22: 252-258.

2 Furlan JC, Fehlings MG. Hyponatremia in the acute stage after traumatic cervical spinal cord injury: clinical and neuroanatomic evidence for autonomic dysfunction. Spine 2009; 34: 501-511.

3 Soni BM, Vaidyanthan S, Watt JW, Krishnan KR. A retrospective study of hyponatremia in tetraplegic/paraplegic patients with a review of the literature. Paraplegia 1994; 32 : 597-607.

4 Nakao Y, Suda K, Shimokawa N, Fu Y. Risk factor analysis for low blood pressure and hyponatremia in acutely and subacutely spinal cord injured patients. Spinal Cord 2012; 50: 285-288.

5 Momi J, Tang CM, Abcar AC, Kujubu DA, Sim JJ. Hyponatremia-What Is Cerebral Salt Wasting? Perm J 2010; 14: 62-65.

6 Laville M, Burst V, Peri A, Verbalis JG. Hyponatremia secondary to the syndrome of inappropriate secretion of antidiuretic hormone (SIADH): therapeutic decision-making in real-life cases. Clin Kidney J 2013; 6: i1-i20.

7 Nagaoka D, Nassar AP Jr, Maciel AT, Taniguchi LU, Noritomi DT, Azevedo LC et al. The use of sodium-chloride difference and chloride-sodium ratio as strong ion difference surrogates in the evaluation of metabolic acidosis in critically ill patients. J Crit Care 2010; 25: 525-531.
8 Kurt A, Ecevit A, Ozkiraz S, Ince DA, Akcan AB, Tarcan A. The use of chloride-sodium ratio in the evaluation of metabolic acidosis in critically ill neonates. Eur J Pediat 2012; 171: 963-969.

9 Story DA, Morimatsu H, Bellomo R. Strong ions, weak acids and base excess: a simplified Fencl-Stewart approach to clinical acid-base disorders. $\mathrm{Br} J$ Anaesth 2004; 92: 54-60.

10 Story DA, Tosolini A, Bellomo R, Leblanc M, Bragantini L, Ronco C. Plasma acid-base changes in chronic renal failure: a Stewart analysis. Int J Artif Organs 2005; 28: 961-965.

11 Klaboch J, Opatrná S, Matousovic K, Sefrna F, Havlín J, Schück O. Acid-base balance in peritoneal dialysis patients: a Stewart-Fencl analysis. Ren Fail 2009; 31: 625-632.

12 Patel GP, Balk RA. Recognition and treatment of hyponatremia in acutely ill hospitalized patients. Clin Ther 2007; 29: 211-229.

13 Halperin ML, Goldstein MB. Fluid, Electrolyte and Acid-Base Physiology - A ProblemBased Approach, 3rd edn. Sanders: Philadelphia, PA, USA, 1999.

14 Fencl V, Jabor A, Kazda A, Figge J. Diagnosis of metabolic acid-base disturbances in critically ill patients. Am J Respir Crit Care Med 2000; 162: 2246-2251.

15 Hoorn EJ, Zietse R. Hyponatremia revisited: translating physiology to practice. Nephron Physiol 2008; 108: 46-59.

16 Greger R, Heidland A. Action and clinical use of diuretics. In: Davison AM, Cameron JS, Grünfeld JP, Kerr DNS, Ritz E, Winearls CG (eds). Oxford Textbook of Clinical Nephrology 2nd edn. Oxford University Press: Oxford, New York, Tokyo, 1998, pp 2679-2706.

17 Verbalis JG, Goldsmith SR, Greenberg A, Korzelius C, Schrier RW, Sterns RH et al. Diagnosis, evaluation, and treatment of hyponatremia: expert panel recommendations. Am J Med 2013; 126: S1-S42.

18 Spasovski G, Vanholder R, Allolio B, Annane D, Ball S, Bichet D et al. Clinical practice guideline on diagnosis and treatment of hyponatraemia. Nephrol Dial Transplant 2014 29: i1-i39.

19 Frisbie JH. Salt wasting, hypotension, polydipsia, and hyponatremia and the level of spinal cord injury. Spinal Cord 2007; 45: 563-568.

20 Jacob G, Ertl AC, Shannon JR, Furlan R, Robertson RM, Robertson D. Effect of standing on neurohumoral responses and plasma volume in healthy subjects. J App/ Physiol 1998; 84: 914-921.

21 Johns EJ. The kidney and the sympathetic nervous system. In: Mathias CJ, Bannister R (eds). Autonomic Failure. A Textbook of Clinical Disorders of the Autonomic Nervous System, 5th edn. Oxford University Press, 2013, p 229.

22 Schrier RW, Bansal S. Diagnosis and management of hyponatremia in acute illness. Curr Opin Crit Care 2008; 14: 627-634.

23 Liamis G, Milionis H, Elisaf M. A review of drug-induced hyponatremia. Am J Kidney Dis 2008; 52: 144-153.

24 Atsariyasing W, Goldman MB. A systematic review of the ability of urine concentration to distinguish antipsychotic- from psychosis-induced hyponatremia. Psychiatry Res 2014; 217: 129-133.

25 Krassioukov AV, Karlsson AK, Wecht JM, Wuermser LA, Mathias CJ, Marino RJ. Joint Committee of American Spinal Injury Association and International Spinal Cord Society. Assessment of autonomic dysfunction following spinal cord injury: rationale for additions to International Standards for Neurological Assessment. J Rehabil Res Dev 2007; 44: 103-112. 